\title{
Effect of different dosages of organic substrate on the catalase activity and the anthocyanins content in the one-year-old shoots of apple tree
}

\author{
Julya $V$. Guryanova ${ }^{1, *}$, Viktor D. Khmyrov ${ }^{2}$, Dmitry $V$. Guryanov ${ }^{3}$, Pavel Yu. Khatuntsev ${ }^{4}$, \\ and Taymaskhan H.-H. Aliev ${ }^{4}$ \\ ${ }^{1}$ Michurinsk State Agrarian University, Department of Horticulture, 393760 Michurinsk, Russia \\ ${ }^{2}$ Michurinsk State Agrarian University, Department of Technological Processes and Technosphere \\ Safety, 393760 Michurinsk, Russia \\ ${ }^{3}$ Michurinsk State Agrarian University, Department of Agroengineering and Electric Power \\ Engineering, 393760 Michurinsk, Russia \\ ${ }^{4}$ Michurinsk State Agrarian University, Department of Agrochemistry, Agroecology and Soil \\ Science, 393760 Michurinsk, Russia
}

\begin{abstract}
Studies were carried out on the catalase and anthocyanins content in the cortex of one-year-old shoots of apple trees using different dosages of introducing an organic substrate at a dose of $10 \mathrm{t} / \mathrm{ha} ; 25 \mathrm{t} / \mathrm{ha} ; 40 \mathrm{t} / \mathrm{ha}$ in the fruit garden. Two varieties were used in the experiments: one of the summer term of ripening-Mechta, and one of winter ripening - Bogatyr, which were grafted onto rootstock 54-118. Studies have shown that the use of an organic substrate at a rate of $10 \mathrm{t} / \mathrm{ha}$ and $25 \mathrm{t} / \mathrm{ha}$ contributed to an increase in frost resistance in both of the studied varieties. Biochemical processes proceeded more smoothly with the addition of $25 \mathrm{t} / \mathrm{ha}$ in both of the studied varieties. Respiratory processes proceeded uniformly, as indicated by the activity of catalase; the accumulation and decrease of anthocyanins were observed according to the regularity of the dormancy period of plants. The dose of 40 t/ha contributed to the inhibition of the regular course of biochemical processes in apple trees, which caused reduction of frost resistance of the apple tree. Such plants are subsequently subject to decrease in frost resistance, and as a result - to yield decrease.
\end{abstract}

\section{Introduction}

Organic fertilizers have long been the best nutrition for production of fruit crops in Russia. Such nutrition contains all the necessary micro and macro elements for the development of crops, improves the composition of soil, its physical and chemical structure. Soils of heavy mechanical composition turn into lighter soils, while sandy soils turn out to be more bounded [1-2]. Organic fertilizers, when applied to the soil, are known to form a higher humus content. At different application rates of the organic substrate, the moisture capacity accordingly changes and the water regime increases or decreases. When such a substrate enters the soil, the number of beneficial microorganisms increases [3]. It has been proven that introduction

\footnotetext{
*Corresponding author: guryanova_70@mail.ru
} 
of organic fertilizers helps to increase frost resistance of plants, which leads to high yields and the ability of trees to grow the vegetative mass [3]. Many authors do not recommend seeking ways of increasing yield in the early years of trees' fruiting, since this indicator reduces the winter hardiness of plants. The high nitrogen content, which is part of the organic matter, contributes to an increase in the vegetative growth of plants, and this factor causes shoot growth and stem thickening [4].

Introduction of organic matter up to $40 \mathrm{t} /$ ha has long been recommended in the Central Chernozem Region. We used different dosages of organic fertilizer. In order to optimize and reduce the costs of organic-mineral mixtures in horticultural farms, we propose to introduce dosages of organic fertilizers of 10 and $25 \mathrm{t} / \mathrm{ha}$. We have discovered previously that the leaf plate increases in winter apple varieties and the chlorophyll content increases as well. An increase in the introduction of organic matter up to $40 \mathrm{t} /$ ha contributed to a decrease in leaf area and inhibition of the passage of biochemical processes in the apple tree. Moreover, weather conditions contributed to the late blooming of the buds, because the spring was observed as cold. The growth of shoots continued until the end of October, which was allowed by high positive temperatures [5-6].

Some authors note that it is necessary to introduce an organic substrate in poor soils of the Non-Chernozem Zone, when the humus content is less than $2 \%$, and, moreover, the application rate should be increased to $100 \mathrm{t} / \mathrm{ha}$. As indicated above, a wide range of macro and micronutrients is contained in the organic matter.

In this regard, the objective of this work was to identify the optimal rate of an organic substrate introduction for increasing the biological potential of apple plants.

\section{Materials and methods}

The research methodology was compiled taking into account the "Programs and methods for variety study of fruit and berry crops" [7]. In our experiments, the studies were carried out on the effect of different dosages of the organic substrate at a rate of $10 \mathrm{t} / \mathrm{ha} ; 25 \mathrm{t} / \mathrm{ha} ; 40 \mathrm{t} / \mathrm{ha}$ in a fruit garden. Manure of cattle, which were housed on deep litter, was used in the experiments, which was processed in a special aerator, and the organic fertilizer was obtained after 7 days, with the following NPK values [8]. The chemical composition of the organic substrate: Potassium (K) was obtained at $175.5 \mathrm{mg} / 100 \mathrm{~g}$ of soil; Phosphorus $(\mathrm{P})-100$ $\mathrm{mg} / 100 \mathrm{~g}$ of soil; Nitrogen (N) (including: nitrate nitrogen $-117.5 \mathrm{mg} / 100 \mathrm{~g}$ of soil; ammonia nitrogen $-31.6 \mathrm{mg} / 100 \mathrm{~g}$ of soil and easily hydrolyzed nitrogen $-69.3 \mathrm{mg})-218.4 \mathrm{mg} / 100 \mathrm{~g}$ of soil. Humus content was observed at $13.7 \mathrm{~g} / 100 \mathrm{~g}$ of soil, $\mathrm{pH} 6.97$ [9]. The fruit garden was located in the Michurinsk district of the Tambov Oblast. The climate was temperate continental. The garden was of an intensive type, planted in 2007 with the contrasted varieties of the winter variety Bogatyr and the summer variety Mechta, which were grafted onto a semi-dwarf rootstock 54-118. Planting scheme was 6x3 m. Content of catalase activity was determined by the standard method of A.I. Ermakov et al.; content of anthocyanins in the cortex of annual shoots of apple trees was determined by the method of Solovieva M.A. [10]. Annual shoots of apple trees were cut by secateurs every four weeks during the period of organic, deep and forced rest in the fruit garden until February, inclusive. 10 shoots were taken in triplicate in the experiments. The results were mathematically processed by analysis of variance. Regression analysis was performed in accordance with the Excel application.

\section{Results and discussion}

Adaptation of woody organisms to adverse environmental factors in winter constantly occurs. With a decrease in temperature in the apple trees, the process of respiration begins to 
decrease. This process is associated with the enzyme - the catalase, which is found in all living organisms and is a protective element from the oxidative processes. Catalase helps the plant to adapt to the growing conditions. It quickly decomposes hydrogen peroxide into gaseous oxygen and water molecules in the apple tree cells; otherwise, peroxide has a detrimental effect on a living organism. Therefore, the role of catalase is very important in the life of a living plant [11].

An example of the catalase decomposition is the respiratory process in the studied apple plants. The cell walls are being strengthened during the passage of such a biochemical process. This is mainly proven by using the organic fertilizers. Many authors also noted the effect of mineral fertilizers on the high content of the enzyme in the leaves during the growing season. As mentioned above, the plant under the influence of such factors is able to actively prepare for wintering by strengthening the walls of the apple tree cells and accumulating nutrients in the storage-organs. It will be easier for them to endure harsh temperature drops, icing, wetting, warming, strong frosty winds and the most vulnerable is the return of frost in spring period (the fourth component of winter hardiness) [12-13].

Therefore, it was interesting to study the analysis of the apple trees' respiration in a fruit garden by catalase activity, especially with the use of different application dosages of the organic substrate, because plants react differently to different doses. It is also indirectly known that the catalase activity characterizes winter hardiness (Table 1).

Table 1. Effect of different doses of organic fertilizers on the catalase content in the one-year-old shoots of apple trees of the scion-rootstock combinations (2016-2017), ml of released oxygen

\begin{tabular}{|c|c|c|c|c|c|c|c|}
\hline \multirow{2}{*}{ Variety } & \multirow{2}{*}{$\begin{array}{c}\text { Introduction } \\
\text { dosage, } \mathrm{t} / \mathrm{ha}\end{array}$} & \multicolumn{6}{|c|}{ Months } \\
\hline & & September & October & November & December & January & February \\
\hline \multirow{4}{*}{$\begin{array}{l}\text { Mechta } \\
\text { (summer } \\
\text { variety) }\end{array}$} & control & 11.0 & 13.2 & 46.0 & 35.3 & 32.6 & 16,5 \\
\hline & 10 & 15.3 & 17.2 & 35.0 & 39.8 & 40.1 & 20,4 \\
\hline & 25 & 14.8 & 19.1 & 58.0 & 40.1 & 38.2 & 39,5 \\
\hline & 40 & 10.6 & 11.8 & 58.0 & 19.6 & 19.4 & 18,6 \\
\hline \multicolumn{2}{|r|}{$\mathrm{HCP}_{05}$} & 0,21 & 0.24 & 0.11 & 0.35 & 0.27 & 0.35 \\
\hline \multirow{4}{*}{$\begin{array}{l}\text { Bogatyr } \\
\text { (winter } \\
\text { variety) }\end{array}$} & control & 42.3 & 64.0 & 46.7 & 45.3 & 20.1 & 16,0 \\
\hline & 10 & 51.4 & 63.0 & 60.1 & 50.9 & 53.2 & 52,1 \\
\hline & 25 & 39.6 & 58.0 & 59.2 & 45.1 & 45.6 & 45,1 \\
\hline & 40 & 32.4 & 62.0 & 24.3 & 27.4 & 32.4 & 41,4 \\
\hline \multicolumn{2}{|r|}{$\mathrm{HCP}_{05}$} & 1,12 & 0.38 & 0.41 & 0.32 & 0.31 & 0.81 \\
\hline
\end{tabular}

The table shows that the catalase activity in September-October was noted in the summer variety Mechta at the level of 10.6-15.3 $\mathrm{ml}$ of released oxygen. There was a sharp increase in the catalase content from 35.0-58.0 $\mathrm{ml}$ in November, since during this period the plants were in the phase of organic dormancy. Upon transition from the organic dormancy phase to the forced dormancy phase, the catalase activity decreased down to $19.4 \mathrm{ml}$. A particularly severe drop was observed with a dose of $40 \mathrm{t} / \mathrm{ha}$. When a dose of $10 \mathrm{t}$ and $25 \mathrm{t} / \mathrm{ha}$ was introduced, a decrease of $39.8 \mathrm{ml}$ and $40.1 \mathrm{ml}$ was observed evenly compared to the control. The catalase activity declined in February, the exception was the option with a dose of $25 \mathrm{t} / \mathrm{ha}$ $(39.5 \mathrm{ml})$. It was this dosage that contributed to active respiration in the summer variety Mechta.

The peak of catalase activity occurred in October in all studied variants of the winter variety Bogatyr $(32.4 \mathrm{ml}-51.4 \mathrm{ml})$. A sharp decrease was noted in the variants with $40 \mathrm{t}$ / ha $(24.3 \mathrm{ml})$ and in the control $(46.7 \mathrm{ml})$ in November. Decrease in catalase activity 
proceeded smoothly from November to February in the variants with the addition of $10 \mathrm{t}$ and $25 \mathrm{t} / \mathrm{ha}$. Such a smooth flow of biochemical processes in the plant has a more positive effect on the further state of trees during the growing season.

Table 2. Effect of different doses of organic fertilizers on the catalase content in the one-year-old shoots of apple trees of the scion-rootstock combinations (2017-2018), ml of released oxygen

\begin{tabular}{|c|c|c|c|c|c|c|c|}
\hline \multirow{2}{*}{ Variety } & \multirow{2}{*}{$\begin{array}{c}\text { Introduction } \\
\text { dosage, t/ha }\end{array}$} & \multicolumn{6}{|c|}{ Months } \\
\hline & & September & October & November & December & January & February \\
\hline \multirow{4}{*}{$\begin{array}{l}\text { Mechta } \\
\text { (summer } \\
\text { variety) }\end{array}$} & control & 19.0 & 18.6 & 35.0 & 32.6 & 31.4 & 18,3 \\
\hline & 10 & 22.5 & 20.1 & 35.0 & 38.4 & 38.5 & 23,0 \\
\hline & 25 & 13.5 & 12.4 & 41.1 & 42.5 & 39.1 & 41,2 \\
\hline & 40 & 19.2 & 16.2 & 39.1 & 19.1 & 21.1 & 19,7 \\
\hline \multicolumn{2}{|r|}{$\mathrm{HCP}_{05}$} & 0,21 & 0.24 & 0.11 & 1.12 & 0.99 & 1.01 \\
\hline \multirow{4}{*}{$\begin{array}{c}\text { Bogatyr } \\
\text { (winter } \\
\text { variety) }\end{array}$} & control & 18.0 & 20.1 & 29.6 & 42.1 & 18.0 & 17,0 \\
\hline & 10 & 20.0 & 21.4 & 23.4 & 50.4 & 49.6 & 46,3 \\
\hline & 25 & 20.0 & 22.3 & 26.5 & 46.7 & 42.4 & 45,1 \\
\hline & 40 & 17.0 & 16.0 & 17.0 & 26.1 & 29.1 & 30,1 \\
\hline \multicolumn{2}{|r|}{$\mathrm{HCP}_{05}$} & 0,45 & 0.37 & 0.51 & 0.25 & 0.61 & 0.61 \\
\hline
\end{tabular}

Catalase activity proceeded uniformly in all variants of the summer variety Mechta from September to October, when the plants were in a phase of deep dormancy. Further, a uniform decrease was noted from November to December in the control variant and in variants with the introduction of $10 \mathrm{t} / \mathrm{ha}$ and $25 \mathrm{t} / \mathrm{ha}$. When $40 \mathrm{t} / \mathrm{ha}$ was added, there was a sharp jump in the decrease in catalase activity from $39.1 \mathrm{ml}$ to $19.1 \mathrm{ml}$. This shows that the trees are not resistant to frost damage, freezing, and burns [14]. In other variants, the activity process was observed evenly through February, inclusive. Moreover, when applying $10 \mathrm{t}$ and $25 \mathrm{t} / \mathrm{ha}$, the indicator was higher compared to the control variant from 42.4 to $50.4 \mathrm{ml}$ of released oxygen. This shows the great resistance of apple trees of the summer variety Mechta to frost tolerance.

Catalase activity proceeded uniformly when the plants were in a state of organic and deep dormancy until December, inclusive, in all studied variants of the winter variety Bogatyr. Further, when the plants transitioned from a deep dormant state to a forced dormant phase, a sharp decrease in the activity of catalase in the control variant was observed from $42.1 \mathrm{ml}$ to $18.6 \mathrm{ml}$ and reached $17.0 \mathrm{ml}$ by February. When $10 \mathrm{t}$ and $25 \mathrm{t} /$ ha were added, the enzyme activity proceeded evenly from $42.4 \mathrm{ml}$ to $46.3 \mathrm{ml}$; when $40 \mathrm{t} / \mathrm{ha}$ was added, this indicator was low compared to other varints and the control variant. The uneven flow of biochemical processes, according to the laws of passage of the dormant period, leads to a decrease in the productive processes of apple trees, and as a result to the loss of full-fledged productivity.

In parallel with the study of the catalase activity of scion-rootstock combinations of apple trees in the autumn-winter period, we studied the content of anthocyanins in annual shoots.

Anthocyanins are a group of water-soluble flavonoids that give the fruit a bright color. Because of this, the fruits become very attractive. The accumulation of anthocyanins enhances the color from light pink to bright red, and sometimes from bright blue to dirty purple. These substances belong to the group of P-active compounds.

We found that the winter period of the apple tree passes through the dormant phases and, in parallel, the accumulation of anthocyanins is associated with these states. This statement has been proved by other authors - accumulation and consumption of dye flows in step with 
the physiological state of trees in the winter [15]. As the plants entered dormancy, the pigment content increased by the middle of the winter period, and it decreased by the end of winter.

Table 3. Effect of different doses of organic fertilizers on the anthocyanins content in the one-yearold shoots of apple trees of the scion-rootstock combinations (2017-2018), $\mathrm{mg} / \%$

\begin{tabular}{|c|c|c|c|c|c|c|c|}
\hline \multirow{2}{*}{ Variety } & \multirow{2}{*}{$\begin{array}{c}\text { Introduction } \\
\text { dosage, } \mathrm{t} / \mathrm{ha}\end{array}$} & \multicolumn{6}{|c|}{ Months } \\
\hline & & September & October & November & December & January & February \\
\hline \multirow{4}{*}{$\begin{array}{l}\text { Mechta } \\
\text { (summer } \\
\text { variety) }\end{array}$} & control & 12.0 & 14.0 & 16.1 & 32.6 & 33.5 & 17,7 \\
\hline & 10 & 14.5 & 16.7 & 18.7 & 39.5 & 40.2 & 23,0 \\
\hline & 25 & 15.0 & 18.9 & 19.5 & 41.5 & 39.6 & 37,5 \\
\hline & 40 & 11.5 & 12.4 & 14.3 & 20.4 & 21.9 & 19,7 \\
\hline \multicolumn{2}{|c|}{$\mathrm{HCP}_{05}$} & 1,2 & 0.9 & 1.1 & 1.3 & 1.6 & 0.8 \\
\hline \multirow{4}{*}{$\begin{array}{l}\text { Bogatyr } \\
\text { (winter } \\
\text { variety) }\end{array}$} & control & 47.5 & 50.1 & 49.6 & 46.1 & 18.9 & 17,0 \\
\hline & 10 & 50.0 & 61.3 & 60.1 & 51.2 & 54.3 & 51,5 \\
\hline & 25 & 41.5 & 59.6 & 58.4 & 44.3 & 46.1 & 44,1 \\
\hline & 40 & 34.5 & 31.4 & 28.9 & 32.1 & 45.3 & 44,2 \\
\hline \multicolumn{2}{|c|}{$\mathrm{HCP}_{05}$} & 1,3 & 0.7 & 1.5 & 1.4 & 1.8 & 1.4 \\
\hline
\end{tabular}

The anthocyanins content was observed uniformly in the summer variety Mehcta during the period of organic dormancy from September to November and ranged from 11.5 to 19.5 $\mathrm{mg} / \%$. Further, the anthocyanins content increased to $40.2 \mathrm{mg} / \%$, when using a dose of 10 $\mathrm{t} / \mathrm{ha}$ and $25 \mathrm{t} / \mathrm{ha}(39.6 \mathrm{mg} / \%)$, compared with the control variant. When we applied $40 \mathrm{t} / \mathrm{ha}$, the anthocyanins content was minimal and did not rise above $21.9 \mathrm{mg} / \%$. Some authors [15] proved that during the period of organic, deep dormancy and during the transition to forced dormancy, there are different indicators in the number of anthocyanins and according to these signs, winter hardiness of the scion-rootstock combinations can be partially predicted. Therefore, it is considered possible to use the accumulation of anthocyanins in annual shoots as an indicator of frost resistance and winter hardiness at the stage of organic and deep dormancy.

The processes proceeded more actively in the winter variety Bogatyr. So, the highest anthocyanins content was noted when $10 \mathrm{t} /$ ha and $25 \mathrm{t} /$ ha were added and ranged from 31.4 $\mathrm{m} / \%$ to $61.3 \mathrm{mg} / \%$ in September-October, compared with the control variant. The high content of anthocyanins contributes to an increase in frost resistance of plants [16-17]. The pigment content was accumulated unevenly and was noted to be low in the variant with a dose of $40 \mathrm{t} / \mathrm{ha}$ in comparison with the control variant. So, the anthocyanins content was noted at the level of $28.9 \mathrm{mg} / \%$ to $34.5 \mathrm{mg} / \%$ from September to December, despite the fact that the plants were in a state of organic dormancy (September-October), and later switched to a deep dormant state (November-December) [18-19]. In January, the content increased sharply to $45.3 \mathrm{mg} / \%$, and throughout February it remained at $44.2 \mathrm{mg} / \%$. 
Table 4. Effect of different doses of organic fertilizers on the anthocyanins content in the one-yearold shoots of apple trees of the scion-rootstock combinations (2018-2019), mg/\%

\begin{tabular}{|c|c|c|c|c|c|c|c|}
\hline \multirow{2}{*}{ Variety } & \multirow{2}{*}{$\begin{array}{c}\begin{array}{c}\text { Introduction } \\
\text { dosage, } \mathrm{t} / \mathrm{ha}\end{array} \\
\end{array}$} & \multicolumn{6}{|c|}{ Months } \\
\hline & & September & October & November & December & January & February \\
\hline \multirow{4}{*}{$\begin{array}{c}\text { Mechta } \\
\text { (summer } \\
\text { variety) }\end{array}$} & control & 11.3 & 13.0 & 13.2 & 16.1 & 17.1 & 12,3 \\
\hline & 10 & 14.5 & 14.0 & 14.1 & 18.3 & 21.3 & 19,6 \\
\hline & 25 & 10.4 & 12.1 & 10.9 & 12.4 & 20.4 & 21,4 \\
\hline & 40 & 11.1 & 9.9 & 8.3 & 10.3 & 19.6 & 14,3 \\
\hline \multicolumn{2}{|c|}{$\mathrm{HCP}_{05}$} & 0,2 & 0.3 & 0.4 & 0.4 & 0.2 & 0.5 \\
\hline \multirow{4}{*}{$\begin{array}{c}\text { Bogatyr } \\
\text { (winter } \\
\text { variety) }\end{array}$} & control & 14.3 & 26.1 & 25.9 & 26.3 & 17.9 & 16,0 \\
\hline & 10 & 18.4 & 29.1 & 31.3 & 29.4 & 31.6 & 30,4 \\
\hline & 25 & $\begin{array}{l}10.7 \\
19.1\end{array}$ & 28.4 & 29.6 & 27.4 & 37.1 & 35,1 \\
\hline & 40 & 12.6 & 17.6 & 15.4 & 18.3 & 20.1 & 19,6 \\
\hline \multicolumn{2}{|c|}{$\mathrm{HCP}_{05}$} & 0,3 & 0.5 & 0.6 & 0.6 & 0.2 & 0.4 \\
\hline
\end{tabular}

Works of many scientists state that rootstocks that contain a high number of anthocyanins in the cells tissues contribute to their increase in the cortex of grafted varieties. That leads the scion-rootstock combination to increased frost resistance [20-21].

\section{Conclusion}

Introduction of the organic fertilizer at a dosage of $10 \mathrm{t} / \mathrm{ha}$ in the summer variety Mechta and the winter variety Bogatyr contributed to the incomplete development of the plant cycle. In this embodiment, respiratory processes and the accumulation of anthocyanins in the autumnwinter period were not fully completed. Such a dosage was not enough for the full growth and development of plants.

Introduction of the organic substrate at a dosage of $25 \mathrm{t} / \mathrm{ha}$ in the summer variety Mechta promoted the active passage of biochemical processes, such as catalase activity and the accumulation of anthocyanins. These processes proceeded uniformly, according to the standards of dormancy period. Upon entering the period of organic dormancy, the accumulation of anthocyanins and the activity of catalase gradually increased. During the transition from the organic dormant phase to the deep dormant phase, the indicators reached a maximum value, and there was a gradual uniform decrease in the forced dormant phase. Moreover, activity of biochemical processes was noted as higher in the winter variety Bogatyr than in the summer variety Mechta.

Introduction of the organic fertilizer at a dosage of $40 \mathrm{t} /$ ha was negatively affected in the both studied varieties. This dosage depressed the passage of biochemical processes. So, in this embodiment, drops of the catalase activity and anthocyanins accumulation were noted in the autumn-winter period. This dosage contributed to an increase in growth processes in the summer period; plants did not have time to get ready for the winter period and as a result they went into the dormant period not prepared.

Hence, we recommend the organic fertilizer application dosage of $25 \mathrm{t} / \mathrm{ha}$, which is the most optimal for growth, development and increase of productivity of apple trees of the summer - Mechta and winter - Bogatyr varieties.

\section{References}

1. A. V. Shchegolkov, B. S. Trufanov, V. D. Hmyrov, V. B. Kudenko, D. V. Guryanov, Yu. V. Guryanova, Nano Hybrids and Composites 13, 130 (2017). DOI: 10.4028/www.scientific.net/NHC.13.130 
2. A. K. Kondakov, Udobrenie plodovyh derev'ev, yagodnikov, pitomnikov i cvetochnyh kul'tur [Fertilization of fruit trees, berry plants, nurseries and flower crops] (BIS, Michurinsk, 2007)

3. Z. A. Metlitsky, O. Z. Metlitsky, Yablonya [Apple Tree] (Kolos, Moscow, 2008)

4. O. A. Greznev, Effektivnost' sistemy nekornevogo mineral'nogo pitaniya yabloni $v$ usloviyah CCHR [Efficiency of the system of non-root mineral nutrition of Apple trees in the conditions of the CDRJ (Michurinsk, 2008)

5. P. Yu. Khatuntsev, T. G.-G. Aliev, Yu. V. Guryanova, N. V. Meshkova, Nauchnotekhnicheskij progress $v$ sel'skohozyajstvennom proizvodstve [Collection of reports of the XIII International scientific and practical conference Scientific and technological progress in agricultural production] 73 (Velikiye Luki State Agricultural Academy, Velikiye Luki, 2018)

6. E. N. Sedov, N. G. Krasova, A. A. Muravyov, M. V. Paliy, Z. M. Serova, Intensivnyj yablonevyj sad na slaboroslyh vstavochnyh podvoyah [Intensive apple orchard on dwarf interstitial stocks] (Russian Research Institute of Fruit Crop Breeding, Zhilina, 2009)

7. E. N. Sedov, T. P. Ogolzova, Programma i metodika sortoizucheniya plodovyh, yagodnyh i orekhoplodnyh kul'tur [The program and methodology of variety studies of fruit, berry and nut-bearing crops] (VNIISPK, Orel, 1999)

8. V. D. Khmyrov, Yu. V. Guryanova, V. B. Kudenko, B. S. Trufanov, The Bulletin of Michurinsk State Agrarian University 6, 55 (2013)

9. Yu. V. Guryanova, Povyshenie zimostojkosti i produktivnosti yabloni regulirovaniem ustojchivosti pokoya organicheskim $i$ mineral'nym pitaniem [Increasing the winter hardiness and productivity of Apple trees by regulating the stability of rest organic and mineral nutrition] (Michurinsk, 2015)

10. M. A. Solov'eva, Metody opredeleniya zimostojkosti plodovyh kul'tur: Metodicheskoe posobie [Methods for determining the hardiness of fruit crops: Methodological guide] (Gidrometeoizdat, Leningrad, 1982)

11. V. F. Matveeva, T. A. Kornatskay, Plodovodstvo 7, 62 (1989)

12. Yu. V. Trunov, Mobilizaciya adaptacionnogo potenciala sadovyh rastenij $v$ dinamichnyh usloviyah vneshnej sredy [Proceedings of conference Mobilization of adaptive potential of garden plants in dynamic environmental conditions] 171 (Vserossijskij selekcionno-tekhnologicheskij institut sadovodstva i pitomnikovodstva, Moscow, 2004)

13. Yu. V. Guryanova, P. Yu. Khatuntsev, V. D. Khmyrov, T. V. Grebennikova, A. A. Gorelov, Yale Journal of Science and Education 1 (2016)

14. V. A. Gudkovsky, N. Ya. Kashirskaya, E. M. Tsukanova, Tematicheskij sbornik nauchnyh trudov [Thematic collection of scientific works], 53 (SKZNIISiV, Krasnodar, 2003)

15. N. G. Krasova, M. A. Makarkina, A. M Galasheva, S. E. Sokolova, Scientific and methodological electronic journal Concept T3, 156 (2013)

16. Yu. V. Guryanova, V. V. Ryazanova, Nauka i obrazovanie: problemy $i$ tendencii razvitiya [Proceedings of international scientific-practical conference Science and education: problems and development trends] 62 (Issledovatel'skij centr informacionnopravovyh tekhnologij, Ufa, 2013)

17. Z. N. Tarova, N. M. Solomatin, L. I. Nikanorova, S. V. Frolova, AGRO XXI 10, 12 (2012) 
18. Z. N. Tarova, R. V. Romanov, E. A. Volodkina, The Bulletin of Michurinsk State Agrarian University 2, 22 (2013)

19. Yu. V. Khatuntseva, Weedy gardening 2, 72 (1999)

20. F. Medel, G. Medel, Proceedings of the International Symposium on Foliar Nutrition of Perennial Fruit Plants, 179 (ISHS, Belgium, 2002)

21. I. Klein, Proceedings of the International Symposium on Foliar Nutrition of Perennial Fruit Plants, 131 (ISHS, Belgium, 2002) 